\title{
Risk factors and injury prevention in elite athletes: a descriptive study of the opinions of physical therapists, doctors and trainers
}

\begin{abstract}
Bruno T. Saragiotto ${ }^{1,2}$, Carla Di Pierro ${ }^{3}$, Alexandre D. Lopes ${ }^{1,2}$
ABSTRACT | Background: Musculoskeletal injuries occur frequently in elite athletes. Understanding what professionals who work with patients with sports injuries think about prevention has been suggested as an important aspect to improve the effectiveness of programs to prevent sports injuries. Objectives: To describe and characterize the opinions of physical therapists, physicians and trainers on 'risk factors' and 'prevention of injury' in elite athletes. Method: This is a qualitative study with semi-structured interviews with members of the medical and technical department of the Brazilian delegation who participated in the Pan American Games of Guadalajara 2011. The interview was conducted using two questions: 1) "What do you think can cause injuries in athletes participating in your sport?" 2) "What do you do to prevent injuries in your sport?" The interviews were analyzed in two stages, the identification of thematic units, followed by the categorization and grouping of thematic units. Results: We interviewed a total of 30 professionals. Regarding question 1 , the main factors attributed as responsible for injury were over-training and incorrect sports techniques. Regarding question 2, the main reported strategies used to prevent injuries were muscle strengthening, nutritional counseling and guidance. Conclusions: The main factors affecting the appearance of lesions were over-training, incorrect sports technique, inadequate nutrition and factors related to the athlete's behavior. The main injury prevention strategies were muscle strengthening, nutritional counseling and guidance.
\end{abstract}

Keywords: athletic injuries; sports; qualitative research; physical therapy.

HOW TO CITE THIS ARTICLE

Saragiotto BT, Di Pierro C, Lopes AD. Risk factors and injury prevention in elite athletes: a descriptive study of the opinions of physical therapists, doctors and trainer. Braz J Phys Ther. 2014 Mar-Apr; 18(2):137-143. http://dx.doi.org/10.1590/ S1413-35552012005000147

\section{Introduction}

Musculoskeletal injuries are common among elite athletes. Although the nature of such lesions varies among the different sports, the vast majority of injuries are due to a combination of factors, whereby it is very difficult to establish the specific mechanism leading to an injury ${ }^{1-3}$. Musculoskeletal injuries usually occur when there is an overload of the musculoskeletal structures that exceeds the ability of regeneration or adaptation ${ }^{1}$. Epidemiological studies conducted at international competitions and Olympic Games found that the rate of injury in athletes varies from $10 \%$ to $65 \%$ and that most of these injuries affect the lower limbs ${ }^{4-7}$. For that reason, the avoidance of sports injuries is the main goal pursued by all professionals involved in sports.
Since the early 1990s, theoretical models for the prevention of sports injuries have been formulated. One of the main models ${ }^{8}$ establishes four steps of action: 1) identification of the magnitude of the problem (prevalence and incidence of injuries); 2) identification of the cause and mechanism of injury; 3) implementation of an intervention strategy aimed at injury prevention; and 4) measurement of the effectiveness of the intervention strategy implemented in step 3 by repeating the assessments indicated in step 1. Another model formulated at that time ${ }^{1}$ focused on the intrinsic and extrinsic risk factors for injury; however, it did not explicitly included behavioral features, nor the beliefs of athletes and professionals involved in sports. Based on the previous models,

\footnotetext{
${ }^{1}$ Master's and Doctoral Programs in Physical Therapy, Universidade Cidade de São Paulo (UNICID), São Paulo, SP, Brazil

${ }^{2}$ São Paulo Running Injury Group (SPRunIG), UNICID, São Paulo, SP, Brazil

${ }^{3}$ Núcleo Paradigma, São Paulo, SP, Brazil

Received: 04/01/2013 Revised: 06/25/2013 Accepted: 10/09/2013
} 
Finch ${ }^{9}$ formulated a new model in 2006 that takes the context of interventions into consideration, including behavioral features of athletes and sports professionals. The inclusion of behavioral features in the strategies for injury prevention is directly emphasized in that model.

Although some studies suggested that behavioral aspects might be key factors for injury prevention, the influence of behavior on the cause and prevention of injuries has been poorly investigated ${ }^{10,11}$. In one recent study, professionals and athletes from various sports were interviewed to characterize their beliefs about the definition of an overuse injury, as well as the risk factors that underlie overuse injuries in the corresponding sports ${ }^{12}$. Many participants integrated somatic, as well as psychological and sociological, factors into the definition of an overuse injury. Most of the risk factors for sports injuries reported by the interviewees were related to the athletes' behavior.

Understanding the beliefs held by professionals involved in high-performance sports related to the cause and prevention of injuries is considered relevant to increase the efficacy of programs for the prevention of sports injuries. These beliefs might contribute to the planning of more adequate interventions and to the selection of strategies for the implementation of such programs ${ }^{9,12}$. Therefore, qualitative approaches are needed, as they favor the understanding of the behaviors and beliefs related to injury prevention. Therefore, the aim of the present study was to characterize the opinions of physical therapists, doctors and trainers assisting elite athletes on the risk factors and prevention of injuries in this population.

\section{Method}

The present research was a qualitative study in which semi-structured interviews were administered to 30 of the 112 members of the technical (coaches and trainers) and medical (physical therapists and doctors) staff assisting the Brazilian athletes who participated in various sports at the 2011 Pan American Games in Guadalajara, Mexico. The same interviewer conducted all the interviews, during which the participants were allowed to talk freely on the topics of interest, while the interviewer did not express her opinion at any moment. The interviews continued until saturation was reached. The study was approved by the Medical Department of the Brazilian Olympic Committee and by the research ethics committee of University City of São Paulo (Universidade Cidade de São Paulo - UNICID), São Paulo, state of São Paulo-SP, Brazil (ruling no. 0083.0.186.000-11). All participants signed an informed consent form.

Before the interviews, the participants provided information on their age, gender, occupation and duration of work experience in high-performance sports. The interview script comprised two questions: 1) What do you think can cause injuries in athletes from your sport? 2) What do you do to prevent injuries in your sport?

The participants' characteristics were subjected to descriptive statistics using Microsoft Office Excel 2010 software. The participants' answers were recorded using an Olympus® Digital VN-8100PC voice recorder and manually transcribed to text files for analysis. Analysis was performed in two steps: 1) identification of thematic units, i.e., the words or expressions that best described the participants' answers (e.g., the thematic unit in the sentence "I believe that poor nutrition might be a cause of injury" is "poor nutrition"), and 2) categorization of the thematic units into themes that best represent them. In regard to question 1, the factors liable to cause injury in athletes according to the participants were divided into intrinsic and extrinsic factors as follows. Intrinsic factors were defined as factors associated with the athletes' individual characteristics, such as anthropometric measurements, nutrition and psychological factors ${ }^{1}$; extrinsic factors were defined as factors related to the environment, climate, equipment and training ${ }^{1}$. In the case of question 2 , which investigated the strategies for injury prevention used by the participants, the thematic units were distributed among categories formulated as a function of their frequency and grouping, including equipment, nutrition, interventions/resources (training or physical therapy), psychological features, behavior and others (assessments, laboratory tests and environment).

\section{Results}

The study included 15 professionals from the technical staff and 15 professionals from the medical staff who assisted athletes participating in the following sports: handball, pentathlon, volleyball, 
soccer, swimming, artistic gymnastics, athletics, weightlifting, shooting, synchronized swimming, basketball, water polo, fencing, rugby and wrestling. The average age of the participants was 41.1 years old (standard deviation - SD: 8.9), and the average work experience in high-performance sports was 13.7 years (SD: 7.5). The average duration of interviews was 7.1 minutes (SD: 4.3). Table 1 describes the frequencies of the categories of risk factors and prevention strategies mentioned by the participants.

Question 1 - What do you think can cause injuries in athletes from your sport?

Factors related to training were mentioned by 25 participants (83\%), and this was the category most frequently mentioned as a cause of injury. Other categories mentioned by the participants were sport technique (46\%), physiological/anatomical factors (43\%), behavioral/cognitive factors $(40 \%)$, sport characteristics and equipment (37\%), nutrition (30\%) and others (26\%).

The intrinsic factors most frequently mentioned by the participants were inadequate sport technique, inadequate nutrition, belief that athletes must tolerate pain, competitiveness and previous injury. The extrinsic factors most frequently mentioned were overtraining, inadequate surface and movements inherent to the particular sport. Table 2 describes the full list of intrinsic factors that were mentioned, and Table 3 lists the extrinsic factors.

Question 2- What do you do to prevent injuries in your sport?

The data relevant to question 2 were distributed among categories of strategies used by the participants for injury prevention. The category training interventions or physical therapy resources was mentioned by 29 participants ( $97 \%$ ), followed by the combination of the categories psychological features and behavioral strategies, which were mentioned by 20 participants $(67 \%)$, and the category nutrition, which was mentioned by half of the participants.

The main strategies the participants reported to use for injury prevention were muscle strengthening, provision of orientation and information on injury prevention and nutritional counseling. Table 4 describes the full list of strategies for injury prevention reported by the participants, except for the psychological features and behavioral strategies, which are described in Table 5.
Table 1. Categories of the risk factors (intrinsic and extrinsic) and prevention strategies reported by the participants.

\begin{tabular}{lc}
\hline Risk of injury & $\%(\mathbf{n})$ \\
Training & $83 \%(25)$ \\
Sport Technique & $46 \%(14)$ \\
Physiological/Anatomical Factor & $43 \%(13)$ \\
Behavioral/Cognitive Factors & $40 \%(12)$ \\
Sport Characteristics & $37 \%(11)$ \\
Equipment & $37 \%(11)$ \\
Nutrition & $30 \%(9)$ \\
Others & $26 \%(8)$ \\
Prevention of injury & \\
Interventions/Resources & $97 \%(29)$ \\
Psychology/Behavior & $67 \%(20)$ \\
Nutrition & $50 \%(15)$ \\
Others & $47 \%(14)$ \\
Equipment & $27 \%(8)$ \\
\hline
\end{tabular}

Values are expressed as percentages (number of participants).

\section{Discussion}

In the present study, 30 professionals from the technical and medical staff assisting the Brazilian delegation to the 2011 Pan American Games in Guadalajara were interviewed. The aim of the study was to investigate the opinions of those professionals on the main factors related to injury occurrence in athletes from various sports, as well as the strategies they use to prevent them. The average age of the participants was 41 years old, and their average work experience in high-performance sports was 13 years. These results indicate that the sample comprised participants with substantial experience in their respective sports. The intrinsic risk factors for injury most frequently mentioned by the participants were inadequate sport technique, inadequate nutrition and the belief that athletes must tolerate pain, and the extrinsic factors more frequently mentioned were overtraining, inadequate surface and the movements inherent to the particular sport.

The extrinsic factors most frequently mentioned by the participants were those related to training, equipment, the environment and the sport characteristics, which include overtraining, insufficient muscle strength, lack of rest, the 
Table 2. Intrinsic factors related to the risk of injury in athletes reported by the participants.

\begin{tabular}{|c|c|c|c|c|}
\hline $\begin{array}{l}\text { Physiological/ } \\
\text { Anatomical }\end{array}$ & Nutrition & Sport technique & Behavioral/Cognitive & Others \\
\hline $\begin{array}{c}\text { Previous injuries } \\
\text { (4) }\end{array}$ & $\begin{array}{l}\text { Incorrect nutrition } \\
\text { (9) }\end{array}$ & $\begin{array}{c}\text { Incorrect } \\
\text { technique (14) }\end{array}$ & Belief of the need to sustain pain (5) & $\begin{array}{c}\text { Genetic } \\
\text { predisposition (2) }\end{array}$ \\
\hline $\begin{array}{l}\text { Athlete's anatomy } \\
\text { (2) }\end{array}$ & $\begin{array}{c}\text { Incorrect } \\
\text { hydration (3) }\end{array}$ & & Competitive/aggressive personality (4) & $\begin{array}{l}\text { Time of sports } \\
\text { practice }\end{array}$ \\
\hline Menstrual cycle (2) & & & Lack of attention/concentration (3) & $\begin{array}{l}\text { Lack of education } \\
\text { (athlete) }\end{array}$ \\
\hline $\begin{array}{l}\text { Inadequate sleep } \\
\text { (2) }\end{array}$ & & & $\begin{array}{l}\text { Lack of athlete's knowledge about injury } \\
\text { or prevention (4) }\end{array}$ & \\
\hline Overweight (2) & & & Emotional stress (4) & \\
\hline \multirow[t]{7}{*}{ Female gender } & & & $\begin{array}{l}\text { Psychologically unprepared } \\
\text { (2) }\end{array}$ & \\
\hline & & & Loss of athlete-coach communication (2) & \\
\hline & & & $\begin{array}{l}\text { Lack of knowledge and care of own } \\
\text { body (2) }\end{array}$ & \\
\hline & & & Motivation with a new type of training & \\
\hline & & & Practice of other sports & \\
\hline & & & Psychiatric disease & \\
\hline & & & Fear of being injured & \\
\hline
\end{tabular}

All these factors are described in the table as they were collected from participants.

Table 3. Intrinsic factors related to the risk of injury in athletes reported by the participants.

\begin{tabular}{|c|c|c|c|}
\hline Equipment & Training & Sport characteristics & Others \\
\hline Inadequate surface (11) & Excessive training (13) & $\begin{array}{l}\text { Movements inherent to the } \\
\text { sport }(11)^{* * *}\end{array}$ & Climate changes (3) \\
\hline Wrong shoes (6) & Lack of strength $(8) *$ & Repetitive movements (7) & Temperature (2) \\
\hline $\begin{array}{l}\text { Bad condition of the equipment } \\
\text { used during training (5) }\end{array}$ & Lack of rest (6) & & $\begin{array}{l}\text { Bad referee conduct } \\
\quad \text { (in a match) }\end{array}$ \\
\hline \multirow[t]{8}{*}{ Weight of the equipment } & Lack of physical conditioning (5) & & \\
\hline & Incorrect physical preparation (4) & & \\
\hline & Instability (proprioception) (4) & & \\
\hline & Lack of flexibility (2) & & \\
\hline & Fatigue $(2)^{* *}$ & & \\
\hline & Increase in training load too fast & & \\
\hline & Inexperience of the athlete & & \\
\hline & $\begin{array}{l}\text { Large number of competitions in } \\
\text { the year }\end{array}$ & & \\
\hline
\end{tabular}

All these factors are described in the table as they were collected from participants. * Included the phrase "muscle imbalance"; ** The fatigue component was not identified; *** Included the phrases changes of direction, deceleration, jump, physical contact and high range of movements.

movements inherent to the particular sport (change of direction, deceleration, jumping, physical contact and movements with a wide range of motion) and repetitive movements, among others. Additionally, in a recent study ${ }^{12}$ in which athletes and professionals were asked to explain their beliefs on overuse injuries, factors related to training and equipment, including overtraining, a fast increase in the training load and changes in training and equipment, were mentioned as risk factors for injuries. Those findings indicate 
Table 4. Prevention strategies reported by the participants.

\begin{tabular}{|c|c|c|c|c|}
\hline Interventions/Resources & Nutrition & Equipment & Sport technique & Others \\
\hline Muscle strength (28)* & $\begin{array}{l}\text { Nutrition support } \\
\text { (12) }\end{array}$ & Tape (3) & $\begin{array}{l}\text { Correction/adjustment } \\
\text { of the sport technique } \\
\text { (6) }\end{array}$ & $\begin{array}{c}\text { Periodic } \\
\text { physiotherapeutic } \\
\text { evaluation (4) }\end{array}$ \\
\hline $\begin{array}{l}\text { Sensory-motor training } \\
\text { (10) }\end{array}$ & $\begin{array}{l}\text { Supplementation } \\
\text { (3) }\end{array}$ & Orthotics (2) & & Early diagnosis (3) \\
\hline Stretching (10) & & Adequate shoes (2) & & Routine tests (3) \\
\hline $\begin{array}{l}\text { Use of ice after } \\
\text { match/training (7) }\end{array}$ & & $\begin{array}{l}\text { Use of protective } \\
\text { equipment }\end{array}$ & & $\begin{array}{l}\text { Environmental } \\
\text { supervision (2) }\end{array}$ \\
\hline Relaxing and rest (5) & & Proper clothes & & Odontology \\
\hline Warm-up (5) & & $\begin{array}{l}\text { Use of mouth } \\
\text { guard }\end{array}$ & & $\begin{array}{c}\text { Environmental security } \\
\text { training }\end{array}$ \\
\hline \multicolumn{5}{|l|}{ Physical conditioning (2) } \\
\hline \multicolumn{5}{|l|}{ Massage (2) } \\
\hline \multicolumn{5}{|l|}{ Active recovery } \\
\hline \multicolumn{5}{|l|}{ Electrotherapy } \\
\hline \multicolumn{5}{|l|}{ Hydrotherapy } \\
\hline Osteopathy & & & & \\
\hline
\end{tabular}

All these factors are described in the table as they were collected from participants. * Included the phrases muscle balance, CORE training, functional training and strength of specific muscles.

Table 5. Psychological aspects and behavioral strategies reported by the participants for injury prevention.

\section{Psychological aspects}

Attention to situations that increase the risk of injury (3)

Comprehension and control of the risks of the sport (2)

$$
\text { Psychological balance (2) }
$$

Knowing your body's limits

Concentration in training

Good communication with the coach

Belief in the prevention strategy adopted

\section{Behavioral strategies}

Orientation and information about injury prevention (conversations, classes, lectures and seminars) (16)

Interdisciplinary structure to make decisions (3)

$$
\text { Psychological evaluation (2) }
$$

Information and orientation for the athletes, their families and the professionals who work with them (2)

$$
\text { Psychological support }
$$

Good athlete-coach communication from the beginning of training

$$
\text { Restrain the practice of other sports }
$$

Tolerate frustrations

All these factors are described in the table as they were collected from participants.

that sports professionals are concerned with the training load imposed on athletes. However, when the professionals were asked about the prevention of sports injuries, the three interventions most frequently mentioned were exercises for muscle strengthening, sensorimotor training and stretching. Therefore, there is no direct relationship between the most frequently mentioned causes of injury and the preventive strategies applied. In the case of overtraining, which was the cause of injury most frequently mentioned, prevention ought to be based on the athletes' recovery, which might be active or passive. However, few recovery strategies were mentioned by the interviewees as a resource for injury prevention.

The strategy for injury prevention most frequently cited by the interviewees was exercises for muscle strengthening, and the vast majority of the participants reported to include this strategy as a part of the athletes' training or clinical treatment. A literature review ${ }^{13}$ found that the number of programs for the prevention of sports injuries based on changes 
in training was larger compared to the number of programs that include changes in equipment or rules and educational strategies. Among the programs based on changes to training as a preventive measure, those focusing on coordination and balance were the most frequent, followed by interventions seeking to increase muscle strength and power ${ }^{13}$. However, few studies were devoted to the development of injury prevention programs for elite athletes ${ }^{2}$.

Approximately $40 \%$ of the interviewees believed that behavioral and cognitive features correlated with the occurrence of injuries, i.e., they believed that how athletes act and think in the course of training and competition and their psychological profile might be associated with the risk of injuries. Among such psychological factors, the one most frequently mentioned by the participants was the belief that athletes must be able to tolerate pain. That belief might contribute to injuries, as although pain is a significant sign indicating that something might be wrong in the body, it is often dismissed by athletes ${ }^{14}$. The motto "no pain, no gain," which permeates the world of high-performance sports, reinforces the belief that the athletes must tolerate pain and thus contributes to athletes grounding their beliefs on a sport ethos built exclusively out of personal experiences. The participants also observed that the athlete's personality is related to the occurrence of injuries, as according to them, athletes with aggressive or competitive personalities might be more prone to injuries. In this regard, several studies showed that although no particular personality profile is associated with higher rates of sports injuries ${ }^{15}$, the athletes who suffer injuries more often exhibit some traits that expose them to higher risk, such as carelessness, lack of attention, anxiety and a spirit of adventure ${ }^{15-19}$.

The provision of information and an orientation to injury prevention was frequently mentioned by the participants. Some studies ${ }^{11,20}$ showed that an orientation to various features of training or rehabilitation might be a key factor for the prevention of sports injuries. A lack of information on such injuries might be the main obstacle hindering the adherence to and efficacy of programs for injury prevention $^{9,21}$. It might also contribute to the development of individual beliefs on how to cope with pain and fatigue that dismiss the need to rest and result in greater physical and psychological stress. More accurate information on how to cope with fatigue, pain and stress, the relevance of rest and the damage associated with inadequate recovery might contribute to reductions in the rate of sports injuries $^{22}$. Therefore, an accurate understanding of athletes' beliefs and experiences, of the mechanisms underlying the communication between coaches and athletes and of the athletes' behavior in training, competition and rest has paramount importance.

For the professionals involved in high-performance sports to make a relevant contribution to injury prevention, they must take the athletes' beliefs and opinions into consideration because, as a rule, the ideas on prevention held by the athletes are quite different from those held by the professionals. The athletes' adherence to injury prevention programs improves when they understand the foundations and believe and trust in the program ${ }^{9}$. We suggest that the athletes' behavioral features and beliefs ought to be taken into consideration in future programs for injury prevention. The athletes should be made aware that their views and ideas on injuries, pain and recovery are an integral part of prevention. For better injury prevention, studies should focus on understanding the contexts within which the prevention program is implemented ${ }^{11,12}$.

One of the limitations of the present study is its sample composition, as only members of the Brazilian delegation were interviewed. They represented only one-third of the members of the technical and medical staff. The opinions of experienced professionals on the causation and prevention of injuries should complement the scientific questions posed by researchers in this field and contribute to the formulation of strategies for the prevention of sports injuries. Although the programs available for injury prevention usually focus on equipment and training methods, the results of the present study indicate that psychological factors should also be included in such programs.

\section{Conclusion}

The main factors reported by the participants as being associated with the occurrence of injuries were overtraining, inadequate sport technique, inadequate nutrition and aspects related to the athletes' behavior. The main strategies for injury prevention reported by the participants were muscle strengthening exercises, nutritional counselling and the provision of an orientation session or information. 


\section{References}

1. Meeuwisse WH, Tyreman H, Hagel B, Emery C. A dynamic model of etiology in sport injury: the recursive nature of risk and causation. Clin J Sport Med. 2007;17(3):215-9. PMid:17513916. http://dx.doi. org/10.1097/JSM.0b013e3180592a48

2. Van Tiggelen D, Wickes S, Stevens V, Roosen P, Witvrouw E. Effective prevention of sports injuries: a model integrating efficacy, efficiency, compliance and risk-taking behaviour. Br J Sports Med. 2008;42(8):64852. PMid:18400875. http://dx.doi.org/10.1136/ bjsm.2008.046441

3. Silva AA, Bittencourt NF, Mendonça LM, Tirado MG, Sampaio RF, Fonseca ST. Analysis of the profile, areas of action and abilities of Brazilian Sports Physical Therapists working with soccer and volleyball. Rev Bras Fisioter. 2011;15(3):219-26. PMid:21829986. http://dx.doi. org/10.1590/S1413-35552011000300008

4. Alonso JM, Junge A, Renstrom P, Engebretsen L, Mountjoy M, Dvorak J. Sports injuries surveillance during the 2007 IAAF World Athletics Championships. Clin J Sport Med. 2009;19(1):26-32. PMid:19124980. http:// dx.doi.org/10.1097/JSM.0b013e318191c8e7

5. Junge A, Engebretsen L, Mountjoy ML, Alonso JM, Renstrom PA, Aubry MJ et al. Sports injuries during the Summer Olympic Games 2008. Am J Sports Med. 2009;37(11):2165-72. PMid:19783812. http://dx.doi. org/10.1177/0363546509339357

6. Lopes AD, Barreto HJ, Aguiar RC, Gondo FB, Neto JG. Brazilian physiotherapy services in the 2007 PanAmerican Games: injuries, their anatomical location and physiotherapeutic procedures. Phys Ther Sport. 2009;10(2):67-70. PMid:19376475. http://dx.doi. org/10.1016/j.ptsp.2008.11.002

7. Arena SS, Carazzato JG. A relaçãoo entre o acompanhamento médico e a incidência de lesões esportivas em atletas jovens de São Paulo. Rev Bras Med Esporte. 2007;13(4):217-21. http://dx.doi.org/10.1590/ S1517-86922007000400001

8. van Mechelen W, Hlobil H, KemperHC. Incidence, severity, aetiology and prevention of sports injuries. A review of concepts. Sports Med. 1992;14(2):82-99. PMid:1509229. http://dx.doi.org/10.2165/00007256-199214020-00002

9. Finch C. A new framework for research leading to sports injury prevention. J Sci Med Sport. 2006;9(12):3-9. PMid:16616614. http://dx.doi.org/10.1016/j. jsams.2006.02.009

10. McGlashan AJ, Finch CF. The extent to which behavioural and social sciences theories and models are used in sport injury prevention research. Sports Med. 2010;40(10):841-58. PMid:20836582. http://dx.doi. org/10.2165/11534960-000000000-00000

11. Verhagen EA, van Stralen MM, van Mechelen W. Behaviour, the key factor for sports injury prevention.
Sports Med. 2010;40(11):899-906. PMid:20942507. http://dx.doi.org/10.2165/11536890-000000000-00000

12. van Wilgen CP, Verhagen EA. A qualitative study on overuse injuries: the beliefs of athletes and coaches. J Sci Med Sport. 2012;15(2):116-21. PMid:22188849. http:// dx.doi.org/10.1016/j.jsams.2011.11.253

13. McBain K, Shrier I, Shultz R, Meeuwisse WH, Klugl M, Garza D, et al. Prevention of sport injury II: a systematic review of clinical science research. Br J Sports Med. 2012;46(3):174-9. PMid:21471144. http://dx.doi. org/10.1136/bjsm.2010.081182

14. Liebenson C. Musculoskeletal myths. J Bodyw Mov Ther. 2012;16(2):165-82. PMid:22464114. http://dx.doi. org/10.1016/j.jbmt.2011.11.003

15. Junge A. The influence of psychological factors on sports injuries. Review of the literature. Am J Sports Med. 2000;28(5 Suppl):S10-5. PMid:11032102.

16. Garcia AP, Aragues GM. Lesiones deportivas y rasgo de ansiedad en los jugadores de futbol. Med Clin (Barc). 1998;111:45-8.

17. JacksonDW,JarrettH,Bailey D, KausekJ, SwansonJ,Powell JW. Injury prediction in the young athlete: a preliminary report. Am J Sports Med. 1978;6(1):6-14. PMid:637184. http://dx.doi.org/10.1177/036354657800600103

18. Lysens RJ, Ostyn MS, Vanden Auweele Y, Lefevre J, Vuylsteke M, Renson L. The accident-prone and overuse-prone profiles of the young athlete. Am J Sports Med. 1989;17(5):612-9. PMid:2610274. http://dx.doi. org/10.1177/036354658901700504

19. Taimela S, Osterman L, Kujala U, Lehto M, Korhonen T, Alaranta H. Motor ability and personality with reference to soccer injuries. J Sports Med Phys Fitness. 1990;30(2):194-201. PMid:2402142.

20. Verhagen EA, van Mechelen W. Sport for all, injury prevention for all. Br J Sports Med. 2010;44(3):158. PMid:20231599. http://dx.doi.org/10.1136/ bjsm.2009.066316

21. Keats MR, Emery CA, Finch CF. Are we having fun yet? Fostering adherence to injury preventive exercise recommendations in young athletes. Sports Med. 2012;42(3):175-84. PMid:22235907. http://dx.doi. org/10.2165/11597050-000000000-00000

22. Christakou A, Lavallee D. Rehabilitation from sports injuries: from theory to practice. Perspect Public Health. 2009;129(3):120-6. http://dx.doi. org/10.1177/1466424008094802

\section{Correspondence}

\section{Bruno Tirotti Saragiotto}

Universidade Cidade de São Paulo (UNICID)

Rua Cesário Galeno, 448, Tatuapé

CEP 03071-000, São Paulo, SP, Brasil

e-mail: bruno.saragiotto@gmail.com 